\title{
Let 1000 Flowers Wilt: The Futility of State-Level Health Care Reform
}

\author{
Peter D. Jacobson" \& Rebecca L. Braun**
}

\section{INTRODUCTION}

Aside from the separation of powers, the genius of the American political system is its federalist structure which allows states to experiment with differing social policies. But the political system has failed in its reliance on states to reform a severely broken health care system. Continued reliance on states to correct the inherent flaws in the nation's health care delivery system is like the oft-repeated description of second marriages: they reflect the triumph of hope over experience. Likewise, state-based reforms reflect a resignation that no federal reform is likely any time soon, rather than a realistic hope that state efforts are likely to succeed.

Despite the accolades accorded to the most recent health reform effort in Massachusetts, it, too, is destined to fail. The odds may be better than establishing democracy in Iraq, but not by much. Nothing in previous state-based health reform experiments predicts that anything short of a national overhaul can succeed. Some problems are perennial to every state and their health system, including rising costs, a growing number of uninsured and underinsured populations, troubled Medicaid budgets, and persistent federal inaction. Despite these obvious barriers, states have been desperate to expand health insurance coverage. Governors around the country think to themselves, "why can't we do that," and since the 1970 s, states have designed a wide variety of plans

\footnotetext{
* J.D., M.P.H., Professor of Health Law and Policy Director, Center for Law, Ethics, \& Health, University of Michigan School of Public Health.

** M.P.H. Candidate (2007), University of Michigan School of Public Health.

1. Clarke Canfield, States Explore Health Reform, BANGoR DaILY NEwS, Dec. 26, 2006, at B5.
} 
to implement statewide health insurance programs. ${ }^{2}$ All these efforts have failed.

This paper will summarize efforts throughout the past thirty years in Hawaii, Oregon, California, Vermont, Maine, and Massachusetts to give a sense of the reasons these states' efforts failed and why. We do not believe that Massachusetts's efforts will be any different than the previous state-level efforts that generated wide national attention, accolades, and claims that the new reforms would be successful. Although the Massachusetts plan has some unique attributes, especially its combination of new innovations and existing strategies, most of its components have been tried before with limited success. Taken together, there appears to be very little difference between other states' plans and the 2006 Massachusetts legislation.

In this paper, we first summarize the history of state health reform efforts and discuss why they have not been successful. We then consider why the Massachusetts effort will not be an exception.

\section{SUMMARY OF RECENT STATE HEALTH REFORM EFFORTS}

State health reform efforts began almost a century ago with highly vocal debates in a number of states. None of these states ultimately enacted legislation, but they set the stage for the current debate over Massachusetts's and other states' efforts. The strongest forces opposing such legislation were state medical societies who were simply too powerful for state initiatives to battle against and survive. ${ }^{3}$

Between 1915 and 1920, eight states (California, Massachusetts, New Jersey, Connecticut, Illinois, Ohio, Wisconsin, and Pennsylvania) investigated the subject of state health reform with official commissions. ${ }^{4}$ In 1919, New York came very close to enacting legislation for universal coverage when State Senator Davenport introduced the "Standard Bill.". The legislation gained considerable support from the New York State

2. See Jonathan Oberlander, Health Reform Interrupted: The Unraveling of the Oregon Health Plan, 2006 HEALTH AFF.: WEB EXCLUSIVES w96, w96 ("Perennial problems . . . and persistent federal inaction ... have spurred states ... to go their own way in health reform ... [T] [Tese states have crafted innovative programs to cover the uninsured ....").

3. See, e.g., Daniel J. B. Mitchell, Impeding Earl Warren: California's Health Insurance Plan that Wasn't and What Might Have Been, 27 J. HEALTH POL. POL'Y \& L. 947, 947-76 (2002) (discussing the California Medical Association's opposition to Earl Warren's California Health Insurance Plan).

4. Milton Terris, National Health Insurance in the United States: A Drama in Too Many Acts, 20 J. PUB. HEALTH POL'Y 13, 13 (1999).

5. Id. at $13-15$. 
Federation of Labor, but was opposed by the state medical society, New York Merchants and Manufacturers Association, and commercial insurance companies. ${ }^{6}$ Opponents labeled the bill as "Bolshevism," and the bill was eventually dropped. ${ }^{7}$

In California, Governor Earl Warren initiated three major health reform attempts starting in 1944. Warren's efforts experienced strong resistance from private insurers, the California Medical Association, and the business community. ${ }^{8}$ Warren later said in his autobiography, "I had given much thought to health problems, and felt the necessity of doing something about them .... I I concluded that if anything was to be done to relieve this tragic situation, it must be a public program, and it should be based on the insurance principle." 9

Now, state medical associations are strong supporters of expanded health insurance coverage. What follows are brief summaries of the major contemporary state health reform plans.

\section{A. Hawaii}

"Hawaii is unique among the states for its nearly universal coverage." $" 10$

To many observers, Hawaii is the only successful state health reform plan in U.S. history because of its employer mandate. Since 1974, Hawaii has required that most businesses provide health benefits to their employees. ${ }^{11}$ Many believe that Hawaii's apparent success with health reform occurred because Hawaii is different than other states. The climate and geography of the state, as well as its low unemployment rate and history of comprehensive employment-based health insurance, are traits considered to be unique to Hawaii. For example, the state's physical distance from the mainland essentially prevents businesses from relocating to another state to avoid the employer insurance mandate. ${ }^{12}$ Despite these claims of success, Hawaii's reform has a number of flaws, and $9 \%$ of its residents remain uninsured. ${ }^{13}$

\section{Id. at 13-14.}

7. Id. at 15.

8. Mitchell, supra note 3, at 947-76.

9. EARL WARREN, THE MEMOIRS OF EARL WARREN 186-87 (1977).

10. Suzanne Rotwein et al., Medicaid and State Health Care Reform: Process, Programs, and Policy Options, 16 Health CARE Fin. ReV. 105, 108 (1995).

11. Lawrence Milke, Health insurance: The Hawail Experience, U.S. Congress OFFICE OF TECHNOLOGY 10 (1993).

12. Id. at 33 .

13. Carmen Denavas-Walt et al., U.S. Census Bureau, Current Population Reports, 
The history of health insurance coverage in Hawaii began in the 1930 s with the sugar and pineapple industries, which provided employees with medical care: through dispensaries, hospitals, and salaried doctors. In 1938, the Hawaii Medical Service Association was formed, and social workers and teachers enrolled in the insurance plan. The plan covered surgery, maternity care, and hospital services. ${ }^{14}$ Beginning in 1946, unions struck for health coverage, but it took until 1974 to enact the health reform bill. ${ }^{15}$ The Hawaii Prepaid Health Care Act (PHCA) passed in June 1974 despite opposition from the Hawaii Medical Association and the Health Insurance Association of America. ${ }^{16}$ As a compromise, the final draft of the bill included a clause that terminated the state program once a federal law was passed. ${ }^{17}$

In 1983, Hawaii became the first and only state to receive an Employee Retirement Income Security Act (ERISA) waiver because ERISA was passed a few months after Hawaii's act. ${ }^{18}$ ERISA preempts state laws, including legislation that relates to an employee benefit plan. Although ERISA does not preempt state insurance regulations, it exempts employee benefit plans from state insurance laws. ${ }^{19}$ The ERISA waiver allowed Hawaii to require employers to offer health care coverage to employees who work more than twenty hours a week. Currently, Hawaii is the only state to successfully implement an employer mandate. ${ }^{20}$

In 1993, Hawaii received a Section 1115 waiver $^{21}$ for a demonstration project, Hawaii QUEST (Quality care, ensuring Universal access, Encouraging efficient utilization, Stabilizing costs, and Transforming the way health care is provided to clients). QUEST aimed

INCOME, POVERTY, AND HEALTH INSURANCE COVERAGE IN THE UNITED STATES: 200527 (2006), http://www.census.gov/prod/2006pubs/p60-231.pdf.

14. MIIKE, supra note 11 , at 6 .

15. Id. at 8 .

16. Id.

17. Id.

18. Id.

19. Peter D. Jacobson \& Scott D. Pomfret, ERISA Litigation and Physician Autonomy, $283 \mathrm{~J}$. AM. MED. ASS'N 921, 922 (2000).

20. MIIKE, supra note 11 , at 5 .

21. Section 1115 of the Social Security Act authorizes the Secretary of Health and Human Services to waive Medicaid rules to allow Medicaid demonstration projects. 42 U.S.C. $\$ 1315$ (a)(1) (2000). Under the waiver, state Medicaid programs can use federal matching funds in ways typically not approved. Id. $\S 1315(\mathrm{a})(2)$. States can expand coverage to those individuals not traditionally covered by Medicaid, provide services not covered by Medicaid, or change the delivery system. Demonstration projects are typically approved for a five-year period, during which they are expected to be budget neutral. Centers for Medicare \& Medicaid Services, Research \& Demonstration Projects-Section 1115, http://www.cms.hhs.gov/MedicaidStWaivProgDemoPGI/ 03_Research\&DemonstrationProjects-Section1115.asp (last visited Apr. 16, 2007). 
to provide coverage to uninsured and underinsured populations without access to employer-sponsored coverage. ${ }^{22}$ In the early 1990 s, Hawaii's Medicaid costs increased over $80 \%$, and QUEST sought to save money by shifting enrollees from public Medicaid to private managed care. ${ }^{23}$ Hawaii also offers a limited benefits package for adults with incomes up to $300 \%$ of federal poverty level (FPL) who have lost Medicaid eligibility. ${ }^{24}$ Even with these efforts, there are reports that QUEST has had an overall negative impact on community health centers because of cutbacks in funding and services. ${ }^{25}$

There are a number of reasons why Hawaii's attempt at health reform will continue to disintegrate in the future. Hawaii, like the rest of the nation, is faced with a growing number of uninsured patients, as well as health care and insurance costs that are spiraling out of control. ${ }^{26}$ One problem with the plan is a low compliance rate and poor enforcement of the employer mandate. Another problem is the fact that the PHCA is fixed in time and cannot be altered because the ERISA waiver restricts changing the law. ${ }^{27}$ This is a problem because the cost of providing health insurance to employees is constantly rising and shows no sign of slowing. Hawaii is faced with the question of whether it has the capacity to handle the costs of the program and how it will deal with the uninsured population. ${ }^{28}$

\section{B. Oregon Health Plan}

"The Oregon Health Plan $[(\mathrm{OHP})]$ gained national attention by changing the focus of health care from who is covered to what is covered." 29

22. Rotwein et al., supra note 10, at 108-09.

23. Annette Gardner \& Deane Neubauer, State Report: Hawaii's Health QUEST, 14 HEALTH AFF. 300, 300 (1995).

24. U.S. Dep't of Health \& Human Services, Health Resources and Services Administration, Hawaii Medicaid \& s-Chip Eligibility, http://www.hrsa.gov/reimbursement/states/Hawaii-Eligibility. htm (last visited Mar. 26, 2007).

25. Gardner \& Neubauer, supra note 23 , at 302-03.

26. See Health Trends in Hawaii: A Profile of the Health Care System, Health MarketUninsured, http://www.healthtrends.org/healthmarketUninsured.aspx (last visited Mar. 6, 2007) (summarizing the issues facing Hawaii and its uninsured population).

27. GWen N. Ouye-Nakama, The hawail Uninsured Project, a historical Overview of Hawall's PREPAID HEALTH CARE ACT 4-5 (2004), available at http://www. healthcoveragehawaii.org/pdf/PHCA\%20Historical\%20Brief.pdf.

28. Id. at 6.

29. Paige R. Sipes-Metzler, Oregon Health Plan: Ration or Reason, 19 J. MED. PHIL. 305, 305 (1994). 
In the late $1980 \mathrm{~s}$, Oregon was one of the states that decided not to wait for national health reform. When it became evident that national reform was unlikely, Oregon took its own initiative and created what policymakers believed to be an innovative reform strategy. ${ }^{30}$ At the time, Oregon faced a $17 \%$ uninsured rate-which was much higher than the national average-as well as constantly rising health care costs. ${ }^{31}$ In 1989 , Oregon enacted a series of health reforms to provide affordable universal health insurance coverage for its residents. ${ }^{32}$ One element of the reforms included an employer mandate, which never went into effect. ${ }^{33}$ Another aspect, and the element that gained the most attention, was the coupling of a Medicaid expansion with limits on covered health services. ${ }^{34}$ Like the other reform efforts under discussion, Oregon's efforts failed.

In 1989, when the OHP was introduced, it was considered unique among state health plans because of a feature that involved ranking the health services that Medicaid would cover--the prioritized list. ${ }^{35}$ To develop the prioritized list, an eleven-member Health Services Commission reviewed medical outcomes data, heard expert testimony, and held community meetings to weigh the cost and clinical effectiveness of each medical service to determine its net benefit. ${ }^{36}$ Oregon's unique system replaced a system that included a comprehensive benefits package with one that limited available benefits in order to cover more people. ${ }^{37}$ The resulting rationing program was a nationally debated and controversial topic; Oregon's section 1115 waiver was not approved until $1993 .^{38}$

Along with the prioritized list, Oregon expanded Medicaid to individuals with incomes up to $100 \%$ of FPL. ${ }^{39}$ Oregon's program also expanded eligibility and utilization of managed care plans, hoping to cover 120,000 additional people with incomes up to $100 \%$ of FPL. ${ }^{40}$ The OHP was initially funded through a tobacco tax. In 2002, the state

30. Howard Leichter, Obstacles to Dependent Health Care Access in Oregon: Health Insurance or Health Care?, 29 J. HEALTH POL. POL'Y \& L., 237, 237 (2004).

31. Id.

32. Oberlander, supra note 2, at w97.

33. Id.

34. Id.

35. Rotwein et al., supra note 10 , at 108.

36. Id.

37. Leichter, supra note 30 , at 246-47.

38. Oberlander, supra note 2 , at w97.

39. Id.

40. Rotwein et al., supra note 10 , at 108. 
attempted to expand Medicaid eligibility again, up to $185 \%$ of FPL, but did not allocate new state funds for the expansion. ${ }^{41}$ To achieve sustainability, the state should have further restricted covered services. ${ }^{42}$

As a result of the OHP, Oregon's uninsured population decreased from $18 \%$ in 1990 to $11 \%$ in 1996 . But the uninsured rate actually increased to $14 \%$ in $2002 .^{43}$ By the end of 2006 , the uninsurance rate was back up to $17 \%$, essentially the same as it was in 1993 when the OHP began. ${ }^{44}$ Proponents of the OHP's goal of universal access were unable to gain political support for an employer mandate. In 2002, about $17 \%$ of Oregon's children were uninsured at some point in the year. ${ }^{45}$ Within a year of implementation, enrollment in the OHP fell by over $53 \%$, and enrollment has been capped at 24,000 individuals since 2004 . $^{46}$ Policymakers instituted a six-month lock-out to those who failed to pay their premiums. Studies found that, as a result of this lock-out, $72 \%$ of enrollees who lost coverage remained uninsured. As premiums rose, the benefit package declined, eliminating dental care, medical supplies, outpatient mental health services, and chemical dependency services. ${ }^{47}$

Health policy planners in Oregon became too ambitious about cost sharing, which hurt the OHP's enrollment. Within four months of implementation, enrollment in the standard OHP plan fell $40 \%$. Reducing the benefit package sharply damaged enrollment, and the removal of mental health and chemical dependency services was very dangerous to many clients. ${ }^{48}$ The OHP was a perfect example of the disparity between policymakers' assumptions of low-income populations and their actual behavior and preferences, including enrollees' price sensitivity. ${ }^{49}$

Budgetary problems led to the plan's disintegration. The recession, a high unemployment rate (the highest in the nation), and a growing uninsured population pressured the system. ${ }^{50}$ Stakeholders started to question the weakening of the plan, and bipartisan support slowly

\footnotetext{
41. Id.

42. Oberlander, supra note 2 , at w98.

43. Leichter, supra note 30 , at 242 .

44. Oberlander, supra note 2 , at w99.

45. Leichter, supra note 30 , at 242.

46. Oberlander, supra note 2 , at w99.

47. Id.

48. Id. at w100.

49. Id.

50. Id. at w100-01.
} 
withered. $^{51}$ Today, enrollment is capped, and the benefits package is very limited. ${ }^{52}$

In some ways, the most important lesson from Oregon is that innovative reforms still confront the brutal paradox of serious fiscal limitations coupled with the public's limited willingness to tolerate restrictions. Oregon's rationing mechanism was attacked from the beginning. It is questionable whether the OHP ever had a realistic chance of success.

\section{Massachusetts I}

"I am very proud of the fact that Massachusetts will be the first state in the country to enact universal health insurance for all its citizens." ${ }^{53}$ "From now on, when the sick land at the doorstep of our health care system, the first questions of them will be, 'Where does it hurt?' not 'How will you pay?" said Michael Dukakis, then governor of Massachusetts. ${ }^{54}$

The 2006 legislation in Massachusetts was not the state's first attempt at health care reform. In 1985, Massachusetts became one of the first states to develop an Uncompensated Care Pool to help pay the costs of caring for uninsured patients, a system which still exists today. ${ }^{55}$ The state's first major health reform was in 1988 under Governor Dukakis, who signed into law the Universal Health Care Law. ${ }^{56}$ The plan included a pay or play provision which required employers with six or more employees to provide health insurance (and pay $80 \%$ of the cost) or be taxed $\$ 1680$ for each employee to cover uncompensated care. ${ }^{57}$ The employer mandate was later repealed, but the plan included a few features that remain today, such as Healthy Start and mandated health insurance for college students. ${ }^{58}$

51. Id. at $\mathrm{w} 101-02$.

52. Id. at $\mathrm{w} 102$.

53. Allen R. Gold, Health Insurance in Massachusetts To Cover All; Victory for Dukakis, N.Y. Times, Apr. 14, 1988, at Al.

54. Robin Toner, Health Insurance and Political Hoopla, N.Y. TIMES, Apr. 21, 1988, at A16.

55. Sharon Silow-Carroll \& Tanya Alteras, The Commonwealth Fund, STRETChing STATE Health CaRe Dollars: INNOVATIVE USE OF UNCOMPENSATED CARE FUNDS 15 (2004), http://www.cmwf.org/usr_doc/784_Silow-Carroll_stretching_uncompensated.pdf.

56. See Toner, supra note $\overline{54}$ (describing Dukakis's signing of the bill); see also JOHN E. MCDONOUGH, EXPERIENCING POLITICS 129 (2000) (giving the law that name).

57. MCDONOUGH, supra note 56, at 262-63.

58. John E. McDonough et al., The Third Wave of Massachusetts Health Care Access Reform, 2006 Health AfF.: Web EXClusives w420, w421. 
As the 1990 s recession deepened and medical inflation increased, William Weld, who opposed the employer mandate, was elected as Governor. The legislative support for the employer requirement waned and the law's implementation was postponed several times. ${ }^{59}$ During the years between 1989 and 1995, the number of uninsured patients in Massachusetts increased from 455,000 to $683,000{ }^{60}$ In 1996, the employer mandate was eventually repealed. ${ }^{61}$

\section{California}

"The promise is of a new way, a better way, a less expensive way for small business to buy health insurance," stated Governor Pete Wilson in $1993 .^{62}$

In the early 1990 s, California had the largest uninsured population in the country-more than $20 \%$ of the state's population (6 million)-and only $54 \%$ of Californians were covered under employer-sponsored private health insurance plans. ${ }^{63}$ In 1993, Governor Wilson signed into law the Health Insurance Plan of California (HIPC) as a test of the health alliance concept ${ }^{64}$ developed by several scholars who viewed it as a market-based mechanism to reduce the number of people without health insurance. The concept was subsequently adapted for the Clinton Health Plan. ${ }^{65}$ The HIPC's primary goals were "to increase [health insurance] coverage by improving affordability and enhancing consumer choice.,"66

At the time, the plan "was the nation's first and largest state-run purchasing alliance for small firms." ${ }^{, 67}$ It was a compromise measure in a political environment that has been described as "contentious, partisan, [and] gridlock." 68 The Governor and legislature were controlled by

59. Id.

60. John E. McDonough et al., Health Care Reform Stages a Comeback in Massachusetts, 336 NEW ENG. J. MED. 148, 148 (1997).

61. McDonough et al, supra note 58 .

62. Jill Matthews Yegian et al., The Health Insurance Plan of California: The First Five Years, 19 HEALTH AFF. 158, 158 (2000).

63. PETER JacobSON ET AL., RAND CORP., STATE Health CaRe Reform INITIATIVES: PROGRESS AND PROMISE 175 (1994).

64. See Emery B. Dowell \& Thomas R. Oliver, State Report: Small-Employer Health Alliance in California, 13 HEALTH AFF. 350, 350 (1994) (stating that the HIPC "has become a laboratory to help test the health alliance concept in the Clinton administration's proposal for national health care reform").

65. Id.

66. Yegian et al., supra note 62 , at 158.

67. Id.

68. JACOBSON ET AL., supra note 63, at 195. 
different political parties and much of their state level health reform was on hold pending the outcome of the Clinton administration's proposed Health Security Act. ${ }^{69}$

The HIPC was the first entity established as a purchasing pool for the small group health insurance market. ${ }^{70}$ It gave employees the choice of their own health plans and was designed for organizations and businesses with between two and fifty employees. It offered nineteen different plans, which in the end may have contributed to the program's downfall because employees had trouble absorbing the differences between the plans. $^{71}$ To participate in the HIPC, at least $70 \%$ of a firm's eligible employees were required to purchase coverage from the pool. ${ }^{72}$ Employers were required to contribute at least $50 \%$ of the plan's monthly premium per enrollee. ${ }^{73}$

The HIPC failed as a health reform in part because there was no employer mandate and in part because it was never an employer's exclusive form of health insurance (as proposed under the Clinton Health Security Act). Lacking these components, the plan had no noticeable impact on the cost of insurance premiums, nor did it significantly reduce the number of uninsured people in California. ${ }^{74}$ As of the year 2000, the HIPC still had not captured much of the small group market, with some estimates hovering around $1 \%{ }^{75}$ One explanation for the demise was a lack of PPOs in the HIPC; now nearly $40 \%$ of employers in California offer their employees the choice of a PPO. ${ }^{76}$

The experiment in California found that a purchasing pool alone was not enough to lower the cost of insurance enough to increase utilization. ${ }^{77}$ This is important because the 2006 Massachusetts legislation counts on the purchasing pool to sustain the reform. In 1999, the HIPC was transferred to the Pacific Business Group on Health

69. Id.

70. Id. at 173

71. See Yegian et al., supra note 62 , at 159 ("[O]ne could argue that the HIPC menu included more than the optional number of plans.").

72. Dowell \& Oliver, supra note 64 , at 351 n.2.

73. Id. at 350 .

74. Yegian et al., supra note 62, at 164 ("[T]he HIPC's experience shows that pooled purchasing alone cannot substantially lower the cost of insurance enough to increase insurance provision among small firms.").

75. Id. at 159 .

76. Id. at 160 .

77. Id. at 164. See also Elliot K. Wicks \& Mark A. Hall, Purchasing Cooperatives for Small Employers Performance and Prospects, 78 MILBANK Q. 511, 521 (2000) (noting that only the California HIPC has implemented a risk-adjusted system "that compensates health plans that enroll a disproportionate number of higher-risk individuals"). 
(PBGH), a nonprofit organization and renamed Pacific Health Advantage (PacAdvantage). Coverage ceased at the end of 2006 when PacAdvantage could no longer offer choice, in part because Blue Cross dropped out of the plan. ${ }^{78}$

One assessment of the California effort noted in 1993 that is still applicable today, states that "the dilemma with small group reform and other incremental steps is that they may deflate pressure for more comprehensive reform without adequately addressing other policy objectives, namely universal access to health care." "California represents the reality of incremental change that relies on a competitive market for cost containment, but takes only modest steps toward addressing the overall problem of health care coverage for uninsured populations." 80

\section{E. Vermont I}

In 1992 Vermont passed comprehensive small market insurance reforms and was considered a leader in state health care reform. ${ }^{81}$ Policymakers believed health reform could be successful in Vermont for a number of reasons, such as the state's relatively low uninsurance rate compared with the national average ( $11 \%$ versus $15 \%)$, lower health care expenditures, ${ }^{82}$ and Vermont's homogeneous, healthy population of just over half a million people. ${ }^{83}$ Vermont also had physician-Governor Howard Dean as a strong supporter of health care reform. ${ }^{84}$

At the beginning, there was considerable optimism that Vermont's strategy would be successful. But the optimism started to fade following the passage of Act 160 in 1992, which created the Vermont Health Care Authority (VHCA). ${ }^{85}$ The law promised "'access to quality health services at costs which are affordable." $" 186$ The VHCA authorized regulators to institute a number of reforms including community rating of nongroup insurance, expanding Medicaid, developing a uniform benefit

78. PacAdvantage, http://pacadvantage.org/brokers/closure.asp (last visited Feb. 26, 2007).

79. JACOBSON ET AL., supra note 63, at 199

80. Id. at 173 .

81. JACOBSON ET AL., supra note 63, at 228

82. Howard Leichter, Health Care Reform in Vermont: The Next Chapter, 13 HEALTH AfF. 78 98 (1994).

83. Id. at 80 .

84. Id. at 79 .

85. Id. at $80-81$

86. Id. at 79 . 
package and a global budget, and preparing both a single-payer system and a multipayer system. ${ }^{87}$

Despite initial bipartisan support, it became obvious to both sides of the debate that the mandate was overly ambitious and ambiguous. ${ }^{88}$ One of the Governor's most crucial supporters, the business community, did not support the plan. "The 1,500-member state Chamber of Commerce opposed both the employer mandates and a single-payer system . ...."90 In general, there was a failure to convince the middle class that the program would be beneficial to them. ${ }^{91}$ The increase in taxes on the individual family was staggering. ${ }^{92}$ For example, "a middle-class family of four with an adjusted gross income of $\$ 60,000$ would have seen its [annual] income tax" increase over 95\% from $\$ 1909$ to $\$ 3714 .{ }^{93}$ Immediately after the story broke in the media, trouble arose. ${ }^{94}$ When a legislative vote came for this "Canadian-style single-payer system," it was defeated 112 to $29 .^{95}$

One of the lessons to learn from Vermont's early failure is the need to convince skeptical interest groups and consumers that health care system reform is imperative and benefits everyone. ${ }^{96}$ Explaining the reform's defeat, Governor Dean said, "'The biggest factor was a climate of fear among the public that reform was going to cost a lot of money. I don't think, when it came to the bottom line, many people care about the uninsured.",97

87. Id. at 80 .

88. Id. at 81 (stating that critics and supporters viewed it as "an overly ambiguous, ambitious, and politically perilous mandate").

89. Id. at $87-88$.

90. Id. at 88 .

91. See id. at 87 ("The divisions, and evolving anxiety, among Vermont legislators mirrored those of the general population and interest groups.").

92. See $i d$. at 91 (noting that "[ $t]$ he shift to tax-based funding was an act of political desperation").

93. Id.

94. See id. ("[O]ne key legislator called it the 'moment health care reform crashed and burned in the House" ").

95. Id. at 92 .

96. See id. at 97 (noting that the failure "to convince Vermonters of the need for comprehensive change ... [was] the major lesson from Vermont").

97. Id. (alterations in original). 


\section{F. Massachusetts II}

The Boston Globe reported:

House Speaker Thomas M. Finneran (D-Mattapan) said a 25-cents-apack cigarette tax increase is the most responsible way to expand health care access in the state.

'It does not revert to the old promises of the past, in which we thought we could provide health care for all and do it on the cheap,' Finneran said. ${ }^{98}$

In 1996, Massachusetts received a Section 1115 waiver for Medicaid requirements and initiated another attempt at health care reform. Representative John E. McDonough introduced the McDonoughMontigny Bill, known by its official title as Chapter 203, hoping to restructure and expand the Medicaid program. ${ }^{99}$ Chapter 203 contained a number of major reforms including renaming the Medicaid program MassHealth, expanding coverage for children, and providing prescription drug assistance for seniors. ${ }^{100}$ Instead of an employer mandate, the plan created an Insurance Partnership program that would offer employee subsidies and employer tax credits to encourage employers to offer health coverage without a formal mandate. ${ }^{101}$ Families and adults unemployed for long periods with household incomes less than $133 \%$ of FPL and children under 12 years with family incomes less than $200 \%$ of FPL would be covered under the plan. ${ }^{102}$

The initiative was to be funded with $\$ 200$ million from the state's uncompensated care pool, federal matching funds, and a 25-cents-perpack tobacco tax increase. ${ }^{103}$ The tobacco tax had the dual goal of reducing cigarette consumption and generating revenue for health care programs. ${ }^{104}$ The 1996 legislation repealed the 1988 Dukakis employer mandate-which was never successfully implemented - and replaced it with the Insurance Reimbursement Program to help small employers. ${ }^{105}$

98. Shelly Murphy, Health Bill OK'd by House Panel: Cigarette-Tax Plan Draws Weld's Fire, Boston GlobE, June 8, 1996, at 13.

99. See McDonough et al., supra note 60 , at $148 \mathrm{n} .6$ (citing chapter 203 as an effort to expand and restructure healthcare).

100. Id. at 149 .

101. Id. at 148 .

102. Id. at $148-49$.

103. Id. at 149 .

104. Id. at 150

105. Id. at 148, 151; Affordable Care Today, Previous Health Care Reform EfForts IN 
As a result of Governor Weld's insistence on not raising taxes or implementing any new taxes, the plan was underfunded and ultimately failed. ${ }^{106}$ The tobacco industry "launched an expensive campaign to block the . . . tobacco tax." 107 To gain business community support, the employer mandate was repealed. ${ }^{108}$ Although not all aspects of the 1996 legislation were successful, several aspects of Chapter 203 did go into effect, including increasing coverage for children. ${ }^{109}$ The Massachusetts model was later used as a model for the national State Children's Health Insurance Program (SCHIP). ${ }^{110}$ In general, Chapter 203 was a political compromise that, like each of the other reforms, did not succeed.

\section{G. Maine}

Health reform has been a hot topic in Maine for well over a decade. In 2003, Maine's state health reform, titled Dirigo Health, was signed into law. It has received considerable national attention and was thought to be a model of health care reform with its goal of providing universal access within the state. The reform's objective was to expand coverage to uninsured individuals, businesses, and municipalities with less than fifty employees, as well as the self-employed. ${ }^{111}$ The plans were to be administered through private health insurance carriers and would provide a comprehensive package of benefits at private insurance market rates. Hospitals would be required to maintain price lists available to patients upon request, and health care practitioners would be required to notify patients in writing of their charges for common services. Dirigo Health was to be funded by contributions from enrolled individuals and small businesses, federal matching funds for low-income families (those below $200 \%$ of FPL), and $\$ 53$ million in state funds. ${ }^{112}$

According to Stuart H. Altman, a professor of health economics at Brandeis University, "'Maine has had a fair amount of problems because it was based on a very questionable idea; it's not going well." 113

\footnotetext{
MA, http:/www.hcfama.org/act/reform101.asp (last visited Mar. 15, 2007).

106. See AFFORDABLE CARE TODAY, supra note 105 ("Governor Weld's proposal was seriously under-funded because of his insistence on no new taxes.”).

107. Id.

108. Id.

109. Id.

110. MCDONOUGH, supra note 56, at 283-84.

111. See NOW: Maine's Dirigo Health Reform Debate, http://www.pbs.org/now/science/ dirigodebate.html (last visited Mar. 26, 2007) (discussing discounted health insurance coverage under the plan).

112. Id.

113. Pam Belluck, Massachusetts Could Serve as a Guide in California's Health Insurance Bid,
} 
Problems thus far have included a high drop-out rate, a low enrollment rate, the high cost to taxpayers, and a lack of support from health insurers. ${ }^{114}$ The law, which was designed to contain health care costs and ensure access to all, has fallen short of its initial goal of insuring 31,000 people in its first year and to cover the state's 135,000 uninsured by 2009. ${ }^{115}$ In the first nine months of 2005, Dirigo Choice covered only 1635 uninsured individuals, with an average cost per enrollee of over $\$ 15,900 .{ }^{116}$ By the end of October 2006, there were less than 13,000 enrollees. ${ }^{117}$ Although only $22.4 \%$ of those who are currently enrolled in Dirigo Choice were uninsured at the time they purchased the statesubsidized insurance, ${ }^{118}$ this percentage far exceeds that achieved by the HIPC. ${ }^{119}$ Nonetheless, Maine has lost its place in the spotlight of health reform. ${ }^{120}$

\section{H. Vermont II}

"I hope to use the coming weeks to convince you that my plan for comprehensive health care reform is both bold and balanced, farreaching and far-sighted," stated Governor Jim Douglas in his 2006 State of the State address. ${ }^{121}$

Vermont is another state that has recently undertaken state health reform with the enactment in May 2006 of the state's Medicaid coverage expansion titled Catamount Health. The program, which goes into effect in October 2007, plans to reduce the number of currently uninsured individuals by offering them the opportunity to enroll in private insurance plans. The program will provide insurance on a sliding scale basis for those with incomes up to $300 \%$ of FPL. Catamount Health has goals of achieving universal access to health care, improving quality, promoting health behavior and disease prevention, and also reducing

N.Y. TIMES, Jan. 10, 2007, at A20.

114. Tarren Bragdon, Maine's State-Run Health Plan Faltering, HEALTH CARE NEwS, Jan. 1, 2006, http://www.heartland.org/Article.cfm?artld=18265.

115. Id.

116. Id.

117. Canfield, supra note 1 , at B1.

118. Bragdon, supra note 114.

119. Wicks \& Hall, supra note 77 , at 517.

120. See Bragdon, supra note 114 ("Since the Dirigo Health reform initiative was passed in June 2003 , it has quickly changed from a model health reform of interest to other states to a cautionary tale of TennCare (Tennessee's failed tax-payer funded, state-run instance program) proportions.")).

121. Press Release, Jason Gibbs, Governor Delivers State of the State (Jan. 5, 2006) available at http://www.vermont.gov/tools/whatsnew2/index.php?topic=GovPressReleases\&id=1657\&v=Article. 
costs. ${ }^{122}$ The new law also includes money to help health care providers manage and coordinate preventive services and chronic diseases, and will implement a pay-for-performance system. ${ }^{123}$ To fund the program, Vermont plans to increase the tobacco tax. ${ }^{124}$

Advocates of the program suggest that over the next five years, as many as 25,000 of the 60,000 uninsured Vermonters will be covered. ${ }^{125}$ Vermont's Senate President, Peter Welch, said, "People who are uninsured benefit and people who are insured benefit. That's the first that that's happened." 126 It seems that Vermont goes further than Massachusetts because its law specifies what is to be included in Catamount Health Insurance and mandates low co-pays and deductibles, while Massachusetts leaves those determinations to the discretion of the private insurer.

Already, a great deal of opposition to the law has emerged, including opposition from small businesses that will be fined $\$ 365$ a year for each full-time employee who is not provided with health insurance. An 80cents-per-pack increase in the tobacco tax has upset the tobacco lobby and Republicans who have already called the taxes "unacceptable" and submitted their own bills to lower insurance rates. ${ }^{127}$ There is very little in the Vermont bill that suggests it will have any more success than the original plan of thirteen years ago.

\section{Massachusetts III-2006}

"This could become a model for other states," stated House Speaker Salvatore F. DiMasi. ${ }^{128}$ "Today, Massachusetts is leading the way with

122. An Act Relating to Health Care Affordability for Vermonters, Pub. Acts No. $191 \S 1981$ (2006), 2006 Vt. Acts \& Resolves 615 (codified as amended at VT. STAT. ANN. tit. 33, § 1981 (2006); see also The State of Vermont Legislature, 2006 Health Care Reform Initiatives, Quick Overview, http://www.leg.state.vt.us/HealthCare/2006_HC_Affordability_Act_Leddy_Summary. htm (last visited Mar. 27, 2007) (describing the goals of the 2006 Health Care Affordability Act).

123. Ross Sneyd, Douglas Sings into Law Catamount Health Initiative, BosTON GLOBE, May 25, 2006, http://www.boston.com/new/local/vermont/articles/2006/05/25/douglas_signs_into_law_ catamount_health_initiative/.

124. An Act Relating to Health Care Affordability for Vermonters, Pub. Acts No. $191 \S 1986(2)$ (2006), 2006 Vt. Acts \& Resolves 615 (to be codified at VT. STAT. ANN. tit. 32, § 7811).

125. Sneyd, supra note 123.

126. Id.

127. Id.

128. William C. Symonds \& Howard Gleckman, The Health-Care Crisis: States Are Rushing In, BUS. WK. ONLINE, Nov. 28, 2005, http://www.businessweek.com/magazine/content/05_48/ c3961054.htm. 
health insurance for everyone, without a government takeover and without raising taxes," stated Governor Mitt Romney. ${ }^{129}$

With no disrespect to the hype surrounding the efforts discussed above, the new Massachusetts law has generated national expectations that are nothing short of transformative. ${ }^{130}$ Alas, the reality is likely to be quite different. In brief, the key elements of the new approach will combine employer mandates with government subsidies. The details, as well as critiques, of the Massachusetts law are covered more fully in other articles in this symposium issue.

\section{Individual Mandate}

By far, the most controversial and landmark aspect of the legislation is the individual mandate. The mandate places responsibility on the individual to obtain health insurance. If an individual can afford insurance and chooses not to purchase it, he or she can be fined. ${ }^{131}$ No other state health reform has included an individual mandate. ${ }^{132}$ The financial penalties will increase up to $50 \%$ of the cost of insurance premiums in 2008 for those individuals who do not report insurance on their income tax filings. ${ }^{133}$

\section{Employer Mandate}

Employers with more than ten employees are required to make a fair and reasonable contribution to each worker's health insurance coverage or else be subject to a $\$ 295$ assessment per employee. "Fair and reasonable" has yet to be defined, thus leading to the plan's uncertainty. Initially, the governor vetoed the employer mandate, but the legislature was able to override the veto. ${ }^{134}$ A free rider surcharge will be triggered

129. Press Release, The Commonwealth of Massachusetts Executive Office of Health and Human Services, Romney Signs Landmark Health Insurance Reform Bill (April 12, 2006) available at http:/www.mass.gov/?pagelD=pressreleases\&agId=Eeohhs2\&prModName=eohhspressrelease \& prFile=pr_060412_reform_bill.xml.

130. See McDonough et al., supra note 58, at w420 (noting that "the statute contains novel elements that have never been attempted in any state, [and] it bears analysis and watching").

131. John Holahan \& Linda Blumberg, Massachusetts Health Care Reform: A Look at the Issues, 2006 HEALTH AFF.: WEB EXCLUSIVES w432, w434.

132. See id. at w432 (noting that Massachusetts will be the first state to achieve universal health care if all of the reforms are applied).

133. Kaiser COMM'N ON MEdicaid and the Uninsured, The Henry J. Kaiser family Found., MasSaChusetTS Health CARE REForm Plan 1 (2006), http://www.kff.org/uninsured/ upload/7494.pdf.

134. Id. 
for employers with more than ten employees who do not offer a Section 125 cafeteria plan for their employees ${ }^{135}$ (enabling workers to pay for health insurance with pretax dollars and purchase insurance through the connector even if there is no employer contribution to the plan). ${ }^{136}$

One interesting aspect to watch will be whether employers expand, maintain, or drop coverage following enactment of the legislation. The assessment fee is intended to serve as an incentive to offer insurance, but it could very well become a viable option for employers to abandon providing insurance. Employers who currently provide insurance may drop their insurance and take the $\$ 295$ assessment fee for each employee because, in most cases, it will be much cheaper to pay the assessment fee than to provide health insurance. There also may be limited incentives for employers who currently do not provide insurance to do so, knowing that their penalty is limited to $\$ 295$ per employee. ${ }^{137}$

\section{The Connector}

One of the main aspects of the Massachusetts reform is the Connector, which will allow groups to purchase insurance. It will also ensure portability of insurance from job to job because more than one employer will be able to contribute to the employee's health insurance premium. ${ }^{138}$ The Connector will act as a facilitator between individuals, small businesses, and private insurance plans to ensure that these plans are of high value and good quality. ${ }^{139}$ Beginning in July 2007, non- and small-group markets will merge, which will allow them to purchase insurance through the Connector at rates lower than exist currently. ${ }^{140}$ Initial estimates suggest premiums may drop up to $24 \% .{ }^{141}$ The Connector is a big undertaking for the state not only because it will have to coordinate insurance plans and approve "affordable" plans but also because it will assume a number of other duties, including determining employee eligibility and collecting premiums. ${ }^{142}$

135. Holahan \& Blumberg, supra note 131, at w434.

136. KAISER COMM'N ON MEDICAID AND THE UNINSURED, supra note 133.

137. Id.

138. COMmonwealth of MASS., Health CARE ACCESS AND AFFodability CONFERENCE COMMITTEE REPORT S. 184-2282, at 1 (2006), http://www.mass.gov/legis/summary.pdf [hereinafter CONFERENCE COMMITTEE REPORT].

139. Id.

140. Id.

141. Id.

142. The Council for affordable health Insurance, Massachusetts' Health Care REFORM Plan: TOO MANY STICKS; NOT ENOUGH CARRots 2-3 (2006), available at http:// www.cahi.org/cahi_contents/resources/pdf/massachusetts.pdf. 


\section{Funding}

The plan is expected to cost $\$ 1.2$ billion over three years and will redistribute existing funding, including Medicaid payments for safety net providers and the uncompensated care pool. New funding will come from employer contributions and General Fund revenues. ${ }^{143}$ The bill will use public funds to cover currently uninsured low-income populations and provide residents of the Commonwealth with more equitable coverage. ${ }^{144}$ Funds will also be raised from the employer mandate and individual mandate fines. ${ }^{145}$ The Massachusetts legislature anticipates that no additional funding will be required, which will be difficult to guarantee. Rising health care costs and the limited promise of new funds suggest uncertainty that the plan will be fully financed in the future. ${ }^{146}$

\section{Commonwealth Care Health Insurance Plan}

The Commonwealth Care Health Insurance Plan (CCHIP) will provide subsidized health insurance for households with income up to $300 \%$ of FPL. CCHIP will be operated by the Connector, and requires no deductibles or premiums for those individuals earning up to $100 \%$ of FPL. ${ }^{147}$

\section{Why Massachusetts Policymakers Think It Will Work}

It seems like the news and commentary about the 2006 legislation is suffused with support for the health care bill. Hundreds of articles have been written about how this is a "model system" and how it will succeed. Other states such as Iowa, New Jersey, Minnesota, and California have inquired about the Massachusetts plan or drafted bills that were inspired by Massachusetts. ${ }^{148}$ Even Senator Edward Kennedy, the incoming chairman of the Senate Committee on Health, Education, Labor, and Pensions, said he would call hearings to explore using the Bay State plan as a national model. ${ }^{149}$

143. KAISER COMM'N ON MEDICAID AND THE UNINSURED, supra note 133.

144. CONFERENCE COMMITTEE REPORT, supra note 138, at 1.

145. Holahan \& Blumberg, supra note 131, at w441.

146. KAISER COMM'N ON MEDICAID AND THE UNINSURED, supra note 133, at 2.

147. Holahan \& Blumberg, supra note 131 , at w434.

148. Susan Milligan, Mass. Health Plan Drawing Interest as Model for US: Universal Care Issue Reemerges, BOSTON GLOBE, Dec. 18, 2006, at A1.

149. Id. 
House Speaker Salvatore DiMasi stated, "It's only fitting that Massachusetts would set forward and produce the most comprehensive, all-encompassing health care reform bill in the country." 150 "Governor Mitt Romney called the legislation, "Something historic, truly landmark, a once-in-a-generation opportunity."151 The Senate President, Robert Travaglini, said, "The eyes of the nation are on us .... We led the way with same-sex marriage, and now we are doing it with health care reform." 152

Those involved in the Massachusetts health care reform enthusiastically believe that Massachusetts will be different for a number of reasons. To begin with, it is a relatively rich state, and with Boston acting as a major player in a health sector with prestigious medical centers and doctors, Massachusetts has more resources than most states to provide care for its uninsured population. More importantly, only about $10 \%$ of Massachusetts' 6.5 million people are uninsured, compared with the national average of $16 \%{ }^{153}$ So far, the measure has support from advocacy groups and insurance companies. And the legislation was the product of a political compromise - the individual mandate favored by the political right, and the employer mandate favored by the political left. ${ }^{154}$ That compromise led one critical commentator to note that "[i]t's a conspiracy of the left and the right." 155

\section{Reasons for Skepticism}

But the question remains: how different is the Massachusetts plan from the numerous attempts over the past thirty years from around the country and within Massachusetts itself? As our review of previous states' efforts indicates, employer mandates and purchasing cooperatives have been tried, as have other approaches, without notable success. What about the Massachusetts plan makes it any different than previous state-based reform efforts? Indeed, Massachusetts is itself not new to reform. Both of its major reforms in the past twenty years have failed. Thus, we are skeptical that this third attempt, which is only slightly

150. Mass. Passes Landmark Healthcare Bill: Measure Requires All Residents To Have Health Insurance By 2007, CBS NEwS, Apr. 5, 2006, http://www.cbsnews.com/stories/2006/04/05/health/ main 1472847.shtml.

151. Id.

152. William C. Symonds, In Massachusetts, Health Care for All?, BUS. WK., Apr. 4, 2006, http://www.businessweek.com/investor/content/apr2006/pi20060404_152510.htm?chan=search.

153. KAISER COMM'N ON MEDICAID AND THE UNINSURED, supra note 133.

154. McDonough et al., supra note 58, at w420-31.

155. Milligan, supra note 148 , at A1. 
different from its previous attempts, will be at all divergent from the historical pattern. ${ }^{156}$ Although the state should be applauded for continuing attempts at reform, the efforts in Massachusetts are likely to mimic the results of other states around the country.

Aside from the historical record, there are several implementation challenges facing the reform effort. For one thing, its success hinges on the simultaneous administration of very complex arrangements. For another, nothing in the law requires that insurance companies provide sick or low-income individuals or families with comprehensive, affordable options. ${ }^{157}$

\section{a. Affordability}

One pressing question is whether these plans will actually be affordable. The plan specifies that the individual mandate can only be enforced if the plans are affordable. ${ }^{158}$ Yet the legislation provides neither a definition for the word "affordable" nor a subsidy schedule for low-income residents. ${ }^{159}$ Legislators have suggested that low-cost products range in price from $\$ 200$ to $\$ 250$ per month. ${ }^{160}$ By comparison, in 2005, the national average monthly premium for an employersponsored insurance plan was $\$ 335 .{ }^{161}$ It will be up to the insurance companies to determine what they will charge, and it will be interesting to see if the plans are actually affordable. ${ }^{162}$ In all likelihood, even these supposedly affordable plans will be too expensive for most uninsured individuals to afford. Another problem is that the law does not require a standardized benefits package, ${ }^{163}$ thus making it hard to compare plans and to ensure that all health plans will maintain a basic level of benefits.

Already, the premium estimates have proven to be unrealistically low. The state panel charged with determining both the monthly premium and the benefits package issued its initial estimates showing that the average monthly premium for an individual will be $\$ 380$ for the

156. See generally McDonough et al., supra note 58, at w420-31 (examining the history of the Massachusetts health care system leading up to, and including, its current state after the enactment of Chapter 58).

157. See KAISER COMM'N ON MEDICAID AND THE UNINSURED, supra note 133, at 2 (noting that the mandate is only enforceable if affordable plans are available).

158. Id.

159. Id.

160. Id.

161. Id.

162. Id.

163. Holahan \& Blumberg, supra note 131 , at w438. 
proposed benefit package. ${ }^{164}$ That figure is likely to be well beyond the means of most uninsured individuals absent considerable state subsidies. The Massachusetts health plan is based on suspect financial foundations with very little cost shifting. Thus, the proclamations of the savings to taxpayers are probably overstated. ${ }^{165}$

\section{b. The Connector}

In all likelihood, the Connector will be dominated by high-deductible plans (including health savings accounts) which will attract a healthier population. Depending on demand, there simply may not be enough subsidy funds to pay for all who request them. If the plans offer a low affordability standard, they will reduce the individual burden but increase the state burden and vice versa. ${ }^{166}$ There is also no requirement within the Connector for a standardized benefits package, making it very hard to compare plans. ${ }^{167}$

\section{c. The Massachusetts Uncompensated Care Pool}

Massachusetts is one of the only states to have an uncompensated care pool. The fund was implemented in 1985 and provides direct subsidies to hospitals and community health centers that provide care to patients without insurance coverage. ${ }^{168}$ One major problem that the fund has faced is unsustainable funding, resulting in changes in the prospective payment to and limits on the reimbursement of primary care services in hospitals. ${ }^{169}$ The current legislation threatens the uncompensated care pool by taking the money from it and redistributing it toward the other aspects of the legislation.

\section{d. ERISA Preemption and the Employer Mandate}

To an important extent, the Massachusetts plan hinges on the success of the employer mandate. But the ability to implement the mandate is likely to face an ERISA preemption challenge. It is well beyond the

164. Alice Dembner, Sticker Shock for State Care Plan, BOSTON GLOBE, Jan. 20, 2007, at Al.

165. T. Miller, Massachusetts: More Mirage than Miracle, 2006 HEALTH AFF.: WEB EXCLUSIVES w420, w451.

166. Holahan \& Blumberg, supra note 131 , at $w 437$.

167. Id. at $\mathbf{w} 438$.

168. Silow-CARROLl \& ALTERAS, supra note 55, at 15.

169. Holahan \& Blumberg, supra note 131 , at w433. 
scope of this article to analyze the issues involved in such litigation. Suffice it to say that Maryland's play or pay attempt, the Fair Share Health Care Fund Act, to force Wal-Mart to provide health insurance or pay a fine per employee, was recently struck down. ${ }^{170}$ The court ruled that ERISA preempted the Maryland scheme because it would ultimately compel employers to restructure their employee benefit plans. ${ }^{171}$ Explicitly, the court rejected Maryland's argument that it was merely imposing a payroll tax if Wal-Mart did not provide insurance. ${ }^{172}$ Whether the same reasoning will apply to the Massachusetts plan remains to be seen. At a minimum, the Maryland case raises serious concerns about the employer mandate's ability to survive the expected ERISA preemption challenge. If the employer mandate is bound to be preempted, would the remainder of the plan collapse?

\section{Future Prospects}

One of the biggest questions about the sustainability of the Massachusetts plan is enforcement. Will these laws actually stick, or, like all the other states that failed, will financial burdens, political issues, and enforcement cause the plan to slowly dissolve? Critics have questioned whether these changes, even if implemented, are simply a few "cosmetic nips and tucks." 173 Keep in mind that the legislation is the state's third attempt at health care reform. It is hard to believe the result will be different this time around. ${ }^{174}$ As two critics argued:

Unfortunately, this week's tableau merely repeats one from 20 years ago when Governor Dukakis was celebrating passage of his universal healthcare bill. That plan imploded within two years, and today about 250,000 more people are uninsured in Massachusetts than the day it was signed. Unfortunately, Massachusetts' new health reform legislation looks set to repeat that disaster. ${ }^{175}$

170. Retail Indus. Leaders Ass'n v. Fielder, Nos. 06-1840, 06-1901, 2007 WL102157, at*15 (4th Cir. Jan. 17, 2007).

171. Id.

172. $\quad$ ld. at $* 9$.

173. Miller, supra note 165 , at $\mathbf{w} 452$.

174. McDonough et al., supra note 58, at w420-31.

175. Steve Woolhandler \& David U. Himmelstein, Massachusetts Health Reform Bill: A False Promise of Universal Coverage, PHYSICLANS FOR A NAT'L HEALTH PROGRAM, April 5, 2006. 


\section{J. California 2007}

"Socialized medicine is not the solution to our state's health care problems," said Governor Arnold Schwarzenegger. ${ }^{176}$

On January 8, 2007, Governor Arnold Schwarzenegger proposed a package of piecemeal health care reforms through which California will attempt to cover its uninsured residents. ${ }^{177}$ This is no easy task. California has by far the most uninsured residents in the country-over 6.5 million people, or more than $20 \%$ of the state's population. ${ }^{178}$ Over 1 million of these people are illegal immigrants. ${ }^{179}$

The plan is expected to cost about $\$ 12$ billion a year and would require employers who do not provide health insurance to contribute to a fund to pay for coverage of the working uninsured. ${ }^{180}$ Physicians would be required to pay $2 \%$ and hospitals $4 \%$ of their revenue to help cover higher reimbursements for those physicians and medical facilities that treat patients in the state Medicaid program, MediCal. ${ }^{181}$ Governor Schwarzenegger's proposal would also extend Medicaid to adults who earn up to $100 \%$ of FPL and for children of families who earn up to $300 \%$ of FPL (regardless of their immigration status). ${ }^{182}$ Adult illegal immigrants would continue to be barred from Medicaid, but would still be entitled to safety net care. ${ }^{183}$ Similar to the Massachusetts plan, there would also be a $4 \%$ tax on the social security wages of businesses that do not provide insurance to their employees, in order to subsidize insurance for the working uninsured. ${ }^{184}$

Almost instantly, Governor Schwarzenegger's plan faced serious opposition from some of his most important allies-physicians, hospital industry executives, and his Republican colleagues. One of the proposal's main deterrents is the tax on physicians' and hospitals' revenues. Ironically, in many cases they are the ones providing services to the uninsured, often with cuts to their pay and revenues already.

176. Press Release, Office of the Governor of Cal., Governor Schwarzenegger Announces Veto of Government-Run Health Care (Sept. 5, 2006), available at http://gov.ca.gov/index.php?/pressrelease/3751/.

177. Jenifer Steinhauer, California Plan for Health Care Would Cover All, N.Y. TIMES, Jan. 9, 2007 , at $\mathrm{Al}$.

178. Id.

179. Id.

180. Id.

181. Id.

182. Id.

183. See id. (stating that illegal immigrants could still get health care "from their countries at the state's hospital system").

184. Id. 
Additionally, even if enacted, the potential ERISA preemption barrier still remains.

\section{Why Previous State Reform EFforts HaVe Not BeEN SUCCESSFUL}

When thinking about the potential success of Massachusetts III and other recent state-level reform efforts, the failed attempts of the past should caution policymakers not to oversell their approach. Many states have seen their number of uninsured patients skyrocket, which has adversely impacted their hospitals, community health centers, and the health of their state. States have tried everything from expanding Medicaid eligibility to imposing employer mandates, yet none of the states' health reforms efforts have been successful. Even the ostensibly successful Hawaii reform has an uninsured rate of $9 \%$ and ongoing fiscal pressures despite its employer mandate. ${ }^{185}$

"For the States, implementation of health care reform has been a difficult task. Although the section 1115 demonstrations remain the most effective way for States to expand coverage to uninsured populations and streamline the Medicaid process, the actual execution of reform plans by States has, at times, been arduous." 186 This assessment, from 1995, remains equally accurate today. Aside from the difficulties of replicating experiences across states, there are few evaluations to learn from in designing and implementing health insurance reforms. That a state may learn from previous failure may help avoid similar mistakes, but it provides little guidance for new innovations.

One question to address is why it has been so difficult to make substantial health care reform gains at the state level. Another question is whether the Massachusetts plan and the other emerging state reform efforts will lead to different results. Has the environment changed sufficiently to provide the means for success?

\section{A. Reasons for Lack of Success}

The primary reason why previous efforts have failed is the sheer scope of the cost and scale of providing insurance for all state residents. In a word, the task is overwhelming. Most of the reforms discussed

185. See supra notes 10-28 and accompanying text (discussing Hawaii's uninsured population and escalating uninsurance rates).

186. Jean I. Thorne et al., State Perspectives on Health Care Reform: Oregon, Hawaii, Tennessee and Rhode Island, 16 HEALTH CARE FIN. REV. 121, 121 (1995). 
above were reasonably well designed and, in many cases, implemented as well as could be expected. Yet the results were consistent: none survived, and very few uninsured individuals received the anticipated benefits. Almost all the plans suffered from inadequate resources, whether in economically vibrant states (Massachusetts and California) or in less economically robust states (Vermont and Maine).

A key assumption in the plans discussed above is that expanding Medicaid or offering insurance will lead uninsured individuals to enroll in the new programs. In many cases, individuals may be offered insurance through their employers, but the premiums are simply too expensive to afford. As an example, the HIPC failed in large part because the state subsidies were inadequate to enable low-wage workers to purchase the coverage.

Equally important, the fiscal climate in the United States is virulently anti-tax. Few politicians are willing to say that universal health care coverage can only be achieved with targeted tax increases. Redistribution of wealth is hardly a winning political platform. In Massachusetts III, for instance, Governor Romney specifically cited the absence of a tax increase in the state's plan. Instead, most of the reforms rely on complex combinations of policy changes. What helps sell a plan like Massachusetts III is that various segments are expected to participate. Each change alone might work, but when the overall success of the plan depends on coordinating several separate policy changes, the probability of success is greatly diminished. What will happen to Massachusetts III if ERISA preempts the employer mandate? Can the plan survive without a key component? Where will the state obtain alternative sources of revenue?

In any event, health insurance is just one area competing for scarce state resources. During the states' fiscal crises of the late 1990s and early 2000 s, policymakers were cutting funds for education, Medicaid, and other social needs. In that environment, it is hardly surprising that health insurance reforms were inadequately funded.

Many states' initiatives seem to start out strong, but as support wanes, so does enforcement. For a plan to be sustainable, political support is necessary throughout the implementation process. Inherently, health care reforms require difficult compromises that result in plans filled with broad general reform strategies that essentially postpone the difficult details. For example, in the 2006 Massachusetts legislation, the crucial term "affordable" in the connector plans has yet to be defined. It is easy to camouflage difficult policy choices and tradeoffs in the initial legislation; this allows politicians to exultantly announce the latest 
solution to the health insurance crisis, while ignoring the inevitable implementation challenges.

Often, initial support is difficult to sustain and obscures the consensus needed to implement comprehensive reform. Oregon's plan presents a good example, especially because other states' plans share many of the problems that undermined the OHP. Simply enacting coverage expansions is not enough to solve the problem, given the shifting political and fiscal environments. For instance, term limits mean that legislatures lack continuity over time, and a newly elected governor may not share an enthusiasm for reform. Reforms can easily lose momentum and fiscal support. Despite the OHP's innovative prioritized list, the initial political support waned as the realities of rationing health care, even for state-provided services, became apparent and increasingly divisive.

Equally important, most states underestimate the actual costs of expanded health insurance coverage and the ability to control those costs. Without serious consideration of cost control, state-led reforms will not be successful. But it seems well beyond the ability of any individual state to control increasing medical inflation. ${ }^{187}$ Several of the state reforms discussed above imploded over increased health care costs.

To be sure, previous outcomes are more than just technical failures. In a country that emphasizes individual responsibility over collective responses to social problems, it is difficult to generate the political will to distribute resources to uninsured populations. There is, after all, a reason why Congress has never enacted universal health insurance.

\section{B. Why Massachusetts III Might Be Different}

Regardless of its dismal historical record, there are reasons to suggest that Massachusetts might be different. As noted above, Massachusetts is a wealthy state with a low uninsurance rate. ${ }^{188}$ The legislation's combination of public and private revenue and buy-in from virtually all stakeholders provides a potentially sound basis for implementation. One significant advantage the plan has over previous efforts is that it requires shared sacrifice. From the innovative individual and employer mandates to the idea of the Connector, the plan goes far beyond previous state health care reform proposals.

187. See Oberlander, supra note 2, at w96-104 (detailing the failure of the Oregon Health Plan).

188. McDonough et al., supra note 58, at w430. 
Two other factors should be noted. First, the plan is politically attractive to both liberals and conservatives. The need is undeniable, and neither political party can rely on previous shibboleths to ignore the problem. Liberals are unlikely to achieve reform at the federal level; for conservatives, the market is unlikely to resolve the problem. Thus, the time may be right for state policymakers to make health reform work and to avoid the implementation barriers encountered elsewhere. Second, Massachusetts has the policy expertise to implement and evaluate the program.

Yet even if Massachusetts III is successful, extrapolating from Massachusetts to other states will be challenging to say the least. The conditions that argue for a successful outcome in Massachusetts are largely absent in other states. A further concern is the possibility that ERISA preemption will undermine key elements that are needed for state reforms to be successful. But at least the components of a successful program may be evaluated and understood.

\section{Why It Is Necessary to Keep Trying}

If the historical record is dismal and the chances of sustainable statelevel health care reform are remote, why bother with it? To begin with, the need continues to increase and some people will be helped. ${ }^{189}$ That is better than nothing. ${ }^{190}$ For those who do not believe national insurance can succeed in the United States as it has in other countries, incremental, state-led reform may be the best option.

Probably the most important reason to support state-based efforts is that the federal government is not likely to enact universal health care any time soon. Even though health care reform is already on the 2008 presidential campaign agenda, there are many reasons to doubt significant action. For those who think the time is right, remember back to 1994 when the political environment seemed propitious for enacting the Clinton Administration's Health Security Act. When the middle class refused to compromise on coverage, the Act collapsed. Today we are in a similar situation.

Another reason to pursue state-level efforts is that some experiments may work, or at least we will learn what does not work. Take Massachusetts III, for example. One way or the other, valuable

189. Peter D. Jacobson et al., Survival Strategies for Michigan's Health Care Safety Net Providers, 40 Health SeRvs. Res. 923, 938 (2005).

190. Id. 
information will emerge on the viability of individual and employer mandates. If they work, we can certainly anticipate such mandates diffusing rapidly to other states. If not, states will have reason to explore other policy options.

One difference from the historical trend is that most previous state efforts have come in isolation from one another. Arguably, the current environment represents a policy cascade, ${ }^{191}$ with several states simultaneously attempting significant health care reforms. Whether a critical mass of state-level efforts will yield different results remains to be seen. But the cascade could well create a better environment, shared knowledge, and a dynamic for change. In particular, if the emerging policy cascade proves to be a populist response to perceived federal and state inaction on a wide variety of domestic policy concerns, the current environment could be a departure from past promises and from replicating previous failures.

Finally, federalism matters. For better or worse (to return to the marriage metaphor), we are stuck with state-level options in the absence of national health insurance. If government is responsible for ensuring some level of access to health care for uninsured populations, federal uniformity may be desirable, but states should also experiment with various approaches and policy alternatives until Congress acts. The federalism question is paramount for discussing access to health care. If health care is considered to have fundamental moral importance, it should arguably be available to all, regardless of where they live. For the foreseeable future, however, health care will not be available to all. As such, the burden falls on those states that are willing to accept the responsibility of caring for their own citizens. The number of states now willing to address the needs of their uninsured populations is encouraging and may put pressure on other states and the federal government to finally accept responsibility. Indeed, a lingering question remains--when does an issue that states have been unable to solve become a national problem?

Our skepticism about the current cascade is the twenty years of consistent failure documented above. Maybe another round of reforms will be successful, but if history repeats itself, or even somewhat mimics itself, it is most likely that we will be in the same place in ten years, writing about such and such plan that failed. Each of the states discussed in this paper was initially optimistic, saying "We will be different

191. See, e.g., Timur Kuran \& Cass R. Sunstein, Availability Cascades and Risk Regulation, 51 STAN. L. REV. 683, 683-767 (1999) (detailing availability cascades and their impact on legislation). 
because ...." Every state that has attempted health insurance reform said "we are different" or "unique" or that this will be a "model for other states."

Yet the same states that initiated health reforms with great fanfare in the early 1990s are back again, with states like Minnesota and Washington requesting information about the Massachusetts health reform plan for implementation in their states. For the most part, the same states that are now interested in developing reforms are the ones that attempted reforms beginning twenty years ago. The current efforts should be applauded. At the same time, it is impossible to assume that anything substantial will happen with a series of piecemeal reforms, which in the end do not fix the problems that our health care system is facing. With rising costs and an ever-shrinking middle class, something radical will need to take place, including addressing health care cost increases. For significant change to take place, we need federal reform. Without federal action, it is unlikely that there will be a significant reduction in the growth of the uninsured population. 